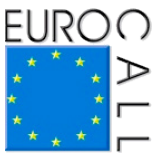

\title{
Telecollaborative games for youngsters: impact on motivation
}

\author{
Kristi Jauregi ${ }^{1}$
}

\begin{abstract}
The present paper describes a case study on the effects of telecollaborative games on learners' motivation. 12 learners from a Dutch and a British secondary school participated in the study. Different games, which included gamification elements, were developed on OpenSim. The overall educational goals of the games were to enhance cultural awareness and intercultural communication of German as a foreign language. Three different cross-cultural groups played the telecollaborative games in two different sessions. Data from pre- and post-surveys were gathered for measuring the impact of telecollaborative games on learners' motivation. At the end of the game sessions, focus group discussions were organised for evaluating the experience. The results indicate that telecollaborative games have a positive impact on learners' motivation.
\end{abstract}

Keywords: virtual worlds, gamification, telecollaboration, motivation, youngsters.

\section{Introduction}

Video games and virtual worlds are viewed as relevant educational tools not just for their potential for entertainment, but also for promoting learning (Prensky, 2007). This is mostly due to game techniques that seem to promote user engagement and motivation. These techniques are increasingly being employed in so-called serious games: games whose main purpose is to educate while entertaining their users. Recently, a growing awareness of the learning potential of games and virtual worlds has been observed in the computer-assisted language learning field (Cornillie, Thorne, \& Desmet, 2012; Jauregi et al., 2011; Panichi \& Deutschmann, 2012; Reinders, 2012; Sykes \& Reinhardt, 2012). This paper presents the results of a case study on the effects of telecollaborative games on learners' motivation, who

1. Utrecht University, Utrecht, Netherlands; k.jauregi@uu.nl

How to cite this article: Jauregi, K. (2016). Telecollaborative games for youngsters: impact on motivation. In S. PapadimaSophocleous, L. Bradley \& S. Thouësny (Eds), CALL communities and culture - short papers from EUROCALL 2016 (pp. 201-207). Research-publishing.net. https://doi.org/10.14705/rpnet.2016.eurocall2016.562 
are learning German as a foreign language in secondary schools. Different cultural games were developed on OpenSim which included several gamification elements. In order to achieve game goals pupils were required to collaborate with peers. They all used German as a lingua franca. The games were played cross-culturally in a virtual international setting. Our approach to the analysis of motivation is based on the self-determination theory framework (Ryan \& Deci, 2000).

\section{Method}

The main research question we address in the present case study is: How do cultural games played cross-culturally in OpenSim influence learners' motivation?

\subsection{Subjects}

12 learners from a Dutch and a British ${ }^{2}$ secondary school participated in the study: ten boys and two girls. They were between 14 and 15 years old. Three crosscultural teams with two Dutch and two British pupils each were created to play the games. The pupils learned German as a foreign language at their school. Their proficiency level ranged between $\mathrm{A} 1$ and $\mathrm{A} 2$. The experience was carried out within the framework of the European TILA project ${ }^{3}$.

\subsection{Games}

Two series of games ${ }^{4}$ were developed in the TILA grid of OpenSim, an open source $3 \mathrm{D}$ virtual environment, where users represented as avatars can communicate using textual chat or voice, move around, interact with objects and engage in action. The games had a German cultural focus. All quizzes, hints and explanations were in German. The gamification elements included both time and point counts.

Each game cycle had five different spaces with a different game in each space. In the first room (see Figure 1), each team member received hints (example of hints: It is a German city. Carnaval is celebrated here. It is in the west) when sitting down around a table. Together the pupils had to be able to create the password that when being written in the chat box would open the door to the next game space.

\footnotetext{
2. Secondary schools: The Ashcombe School, Dorking, United Kingdom. Pleincollege Nuenen, Nuenen, The Netherlands.

3. Telecollaboration for Intercultural Language Acquisition: www.tilaproject.eu

4. The games were developed by the collaborating teachers at both schools: Helen Meyer and Bart Pardoel. Nick Zwart developed the games in OpenSim.
} 
Figure 1. First room in the cultural German game

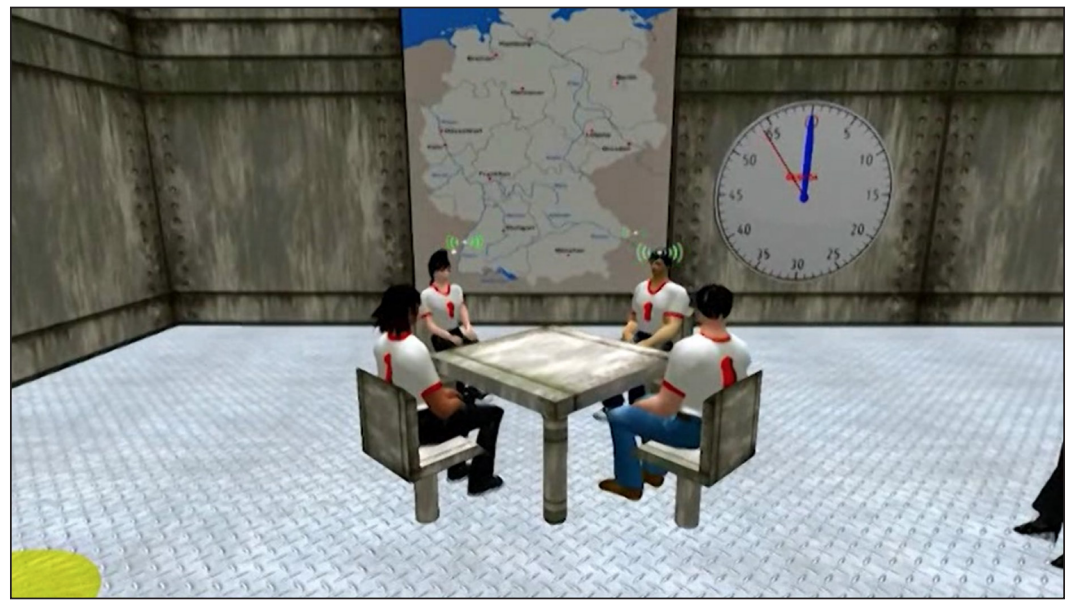

Figure 2. Pupils playing the game on the German cultural quizzes

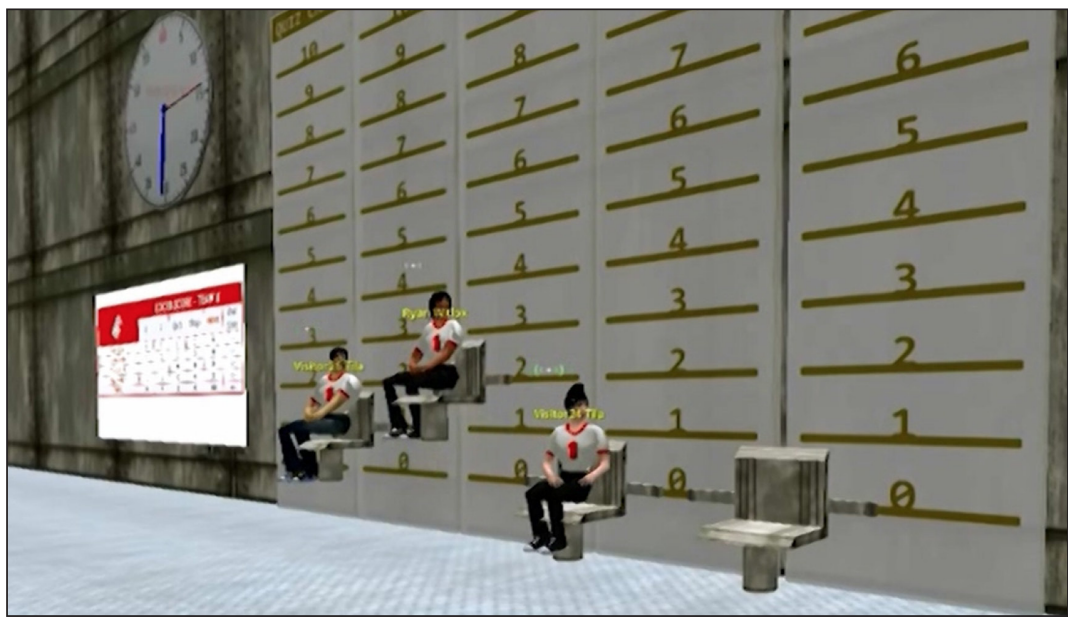

In the second room the hints appeared in the walls when standing on specific yellow plates (examples First day of the week... The opposite of west... The opposite of north... No right hand...). The team members had to discover a five-letter word (example: the name of a German river). In the third game room the group split up into two dyads. The two dyads had to cooperate to build a bridge with the blocks floating on the water and be able to cross the water to continue with the last games. The builders had to communicate purposefully with the other dyad, as these were 
the ones who could move the blocks by following the directions provided by the builders and the other way round. In the fourth game room there were four quiz chairs. When sitting on the chair the pupils got the quiz in the form of multiple choice questions (example of questions: In which country is German not an official language? In which city was the wall? How many inhabitants has Germany?). If they knew the right answer they got a point and the chair raised automatically (see Figure 2). All team members had the same quiz questions and were expected to discuss and share the answers in order to be able to get the highest amount of points with the whole team.

In the final game room, the pupils had to find the right ingredients for two different German recipes displayed on the walls. If they clicked on the wrong ingredient they got a point deducted. When clicking on the right ingredient they received a point. The winner was the team with the most points in the shortest period of time.

\subsection{Motivation surveys}

Several surveys were developed:

- A background survey, that included biographic information and language learning experience. It was filled by all participants before playing the games.

- The user experience survey gathered information about the game and was filled in after each game session.

- A post-survey on the general experience was filled in after the second game session.

In this short paper we will be presenting the results of the user experience survey and will compare the results per game and pupil cluster. For the closed items a five-point Likert scale was used with low values indicating non agreement and high values total agreement.

\section{Results}

Mean and Standard Deviation (SDev) values were calculated for the different items. The pupils enjoyed the German cultural game being played cross-culturally among Dutch and British pupils. Technically, they found it easy to play the game 
and the sound and video quality were very good, particularly in the second game session (see Table 1).

Table 1. SDev values on technical issues for the British and Dutch pupils playing Games

\begin{tabular}{|l|l|l|l|l|l|l|l|l|}
\hline \multirow{2}{*}{\multicolumn{2}{c|}{ Item }} & \multicolumn{3}{c|}{ British } & \multicolumn{4}{c|}{ Dutch } \\
\cline { 2 - 10 } & \multicolumn{2}{c|}{ Game 1 } & \multicolumn{2}{c|}{ Game 2 } & \multicolumn{2}{c|}{ Game 1 2 } \\
\hline Technology & Mean & SDev & Mean & SDev & Mean & SDev & Mean & SDev \\
\hline It was easy to USE the game & 3.6 & 0.5 & 4.2 & 0.8 & 4.2 & 0.4 & 4.5 & 0.5 \\
\hline SOUND was good & 3.8 & 0.4 & 3.8 & 0.8 & 3.6 & 0.9 & 4.5 & 0.5 \\
\hline VIDEO was good & 3.5 & 0.6 & 4.3 & 0.5 & 4.4 & 0.5 & 4.7 & 0.5 \\
\hline
\end{tabular}

Pupils liked very much to communicate and interact in the game environment with pupils from other countries (see Table 2). They liked the game environment and being an avatar. Interestingly, the scores of the British pupils in the second game are much higher than in the first game session, while for the Dutch ones the scores on the second game were a little bit lower than in the first game, but still very high (mean values above 4.0).

Table 2. Values for pupils' preferences and likes

\begin{tabular}{|c|c|c|c|c|c|c|c|c|}
\hline \multirow[b]{3}{*}{ Preferences \& Likes } & \multicolumn{4}{|c|}{ British } & \multicolumn{4}{|c|}{ Dutch } \\
\hline & \multicolumn{2}{|c|}{ Game 1} & \multicolumn{2}{|c|}{ Game 2} & \multicolumn{2}{|c|}{ Game 1} & \multicolumn{2}{|c|}{ Game 2} \\
\hline & Mean & SDev & Mean & SDev & Mean & SDev & Mean & SDev \\
\hline I like to communicate and interact in this game environment & 3.8 & 0.4 & 4.5 & 0.5 & 4.6 & 0.5 & 4.2 & 0.8 \\
\hline I like to meet students from other countries in this game environment & 4.2 & 0.8 & 4.7 & 0.5 & 4.6 & 0.5 & 4.2 & 0.8 \\
\hline I like to learn in this game environment & 4.0 & 0.0 & 4.5 & 0.8 & 4.4 & 0.5 & 4.0 & 0.9 \\
\hline I like to be an avatar & 4.6 & 0.5 & 4.5 & 0.5 & 4.4 & 0.5 & 4.3 & 0.8 \\
\hline
\end{tabular}

As to satisfaction and ease factors, British pupils seem to have felt more comfortable and co-present in the second game than in the first one, scores reaching very high values. The Dutch pupils felt very positive about the games but the scores in the second were slightly lower (see Table 3).

Table 3. Values for pupils' satisfaction and ease issues

\begin{tabular}{|c|c|c|c|c|c|c|c|c|}
\hline \multirow[b]{2}{*}{ Item } & \multicolumn{4}{|c|}{ British } & \multicolumn{4}{|c|}{ Dutch } \\
\hline & \multicolumn{2}{|c|}{ Game 1} & \multicolumn{2}{|c|}{ Game 2} & \multicolumn{2}{|c|}{ Game 1} & \multicolumn{2}{|c|}{ Game 2} \\
\hline Feel & Mean & SDev & Mean & SDev & Mean & SDev & Mean & SDev \\
\hline I felt comfortable during the game & 3.8 & 0.4 & 4.7 & 0.8 & 4.2 & 0.4 & 4.2 & 0.8 \\
\hline I felt I was in the same place with the others & 3.8 & 0.4 & 4.2 & 1.3 & 4.2 & 0.4 & 3.7 & 1.0 \\
\hline I felt satisfied with the way I communicated & 3.8 & 0.4 & 4.0 & 0.9 & 4.0 & 0.0 & 3.8 & 1.0 \\
\hline I felt the game environment affected in my communication positively & 4.0 & 0.0 & 4.5 & 0.8 & 4.2 & 0.4 & 4.0 & 1.1 \\
\hline I felt part of a group & 4.0 & 0.0 & 4.2 & 1.3 & 4.0 & 0.7 & 4.3 & 0.5 \\
\hline
\end{tabular}

Finally, pupils were very enthusiastic about the game and the possibility to play it with pupils from another country. They would recommend to other pupils to play 
these games and they would themselves like to engage in these kinds of games more frequently (see Table 4). All values were very positive. Yet it was remarkable that the scores of British pupils were considerably higher in the second game than in the first one.

Table 4. Overall game experience

\begin{tabular}{|c|c|c|c|c|c|c|c|c|}
\hline \multirow[b]{2}{*}{ Item } & \multicolumn{4}{|c|}{ British } & \multicolumn{4}{|c|}{ Dutch } \\
\hline & \multicolumn{2}{|c|}{ Game 1} & \multicolumn{2}{|c|}{ Game 2} & \multicolumn{2}{|c|}{ Game 1} & \multicolumn{2}{|c|}{ Game 2} \\
\hline Game & Mean & SDev & Mean & SDev & Mean & SDev & Mean & SDev \\
\hline I enjoyed communicating with students from another country & 4.2 & 0.4 & 4.7 & 0.5 & 4.2 & 0.4 & 4.0 & 1.1 \\
\hline I enjoyed the game & 4.0 & 0.0 & 4.4 & 0.9 & 4.6 & 0.5 & 4.7 & 0.5 \\
\hline Because there was interaction with pupils from other countries... & 4.0 & 0.0 & 4.6 & 0.5 & 4.6 & 0.5 & 4.7 & 0.5 \\
\hline I found the game useful for my language learning & 4.0 & 0.0 & 4.6 & 0.5 & 4.4 & 0.5 & 4.2 & 0.8 \\
\hline I would suggest to a friend to take part in this kind of international games & 4.0 & 0.0 & 4.6 & 0.5 & 4.6 & 0.5 & 4.2 & 0.8 \\
\hline I would like to use games with pupils from other countries more often & 4.0 & 0.0 & 4.6 & 0.5 & 4.6 & 0.5 & 4.3 & 0.5 \\
\hline
\end{tabular}

\section{Conclusions}

Pupils greatly enjoyed playing the cultural games with peers from another country. Interestingly, Dutch pupils were very positive about the telecollaborative game experience from the very beginning, while the British pupils started quite cautiously in the first game but grew considerably in self-confidence and satisfaction in the second game. This case study seems to indicate that serious games played telecollaboratively can contribute to boost the learners' motivation to learn foreign languages meaningfully and playfully. Additional research is needed to confirm these initial findings.

\section{Acknowledgements}

We would like to thank the pupils, the teachers (H. Meyer \& B. Pardoel), the OpenSim expert, N. Zwart, and the TILA project.

\section{References}

Cornillie, F., Thorne, S. L., \& Desmet, P. (2012). ReCALL special issue. Digital games for language learning: challenges and opportunities. ReCALL, 24(3), 243-256.

Jauregi, K., Canto, S., De Graaff, R., Koenraad, T., \& Moonen, M. (2011). Verbal interaction in Second Life towards a pedagogic framework for task design. Computer Assisted Language Learning Journal, 24(1), 77-101. https://doi.org/10.1080/09588221.2010.538699 
Panichi, L., \& Deutschmann, M. (2012). Language learning in virtual worlds: research issues and methods. In D. Melinda \& R. O'Dowd (Eds), Researching online foreign language interaction and exchange: theories, methods and challenges (pp. 205-232). Bern: Peter Lang Publishing Group.

Prensky, M. (2007). Digital game-based learning. Paragon House.

Reinders, H. (Ed.). (2012). Digital games in language learning and teaching. Palgrave McMillan.

Ryan, R. M., \& Deci, E. L. (2000). Self-determination theory and the facilitation of intrinsic motivation, social development, and well-being. American Psychologist, 55(1), 68-78.

Sykes, J., \& Reinhardt, J. (2012). Language at play: digital games in second and foreign language teaching and learning. In J. Liskin-Gasparro \& M. Lacorte (Eds), Second language classroom instruction. Series on theory and practice. Pearson-Prentice Hall. 


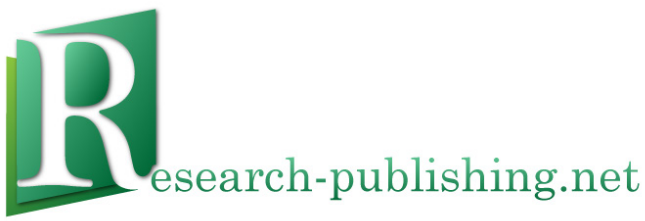

Published by Research-publishing.net, not-for-profit association Dublin, Ireland; Voillans, France, info@research-publishing.net

(C) 2016 by Editors (collective work)

(C) 2016 by Authors (individual work)

\section{CALL communities and culture - short papers from EUROCALL 2016 Edited by Salomi Papadima-Sophocleous, Linda Bradley, and Sylvie Thouësny}

Rights: All articles in this collection are published under the Attribution-NonCommercial -NoDerivatives 4.0 International (CC BY-NC-ND 4.0) licence. Under this licence, the contents are freely available online as PDF files (https://doi. org/10.14705/rpnet.2016.EUROCALL2016.9781908416445) for anybody to read, download, copy, and redistribute provided that the author(s), editorial team, and publisher are properly cited. Commercial use and derivative works are, however, not permitted.

\section{(9) $\Theta \Theta$}

Disclaimer: Research-publishing.net does not take any responsibility for the content of the pages written by the authors of this book. The authors have recognised that the work described was not published before, or that it is not under consideration for publication elsewhere. While the information in this book are believed to be true and accurate on the date of its going to press, neither the editorial team, nor the publisher can accept any legal responsibility for any errors or omissions that may be made. The publisher makes no warranty, expressed or implied, with respect to the material contained herein. While Research-publishing.net is committed to publishing works of integrity, the words are the authors' alone.

Trademark notice: product or corporate names may be trademarks or registered trademarks, and are used only for identification and explanation without intent to infringe.

Copyrighted material: every effort has been made by the editorial team to trace copyright holders and to obtain their permission for the use of copyrighted material in this book. In the event of errors or omissions, please notify the publisher of any corrections that will need to be incorporated in future editions of this book.

Typeset by Research-publishing.net

Cover design by (C) Easy Conferences, info@easyconferences.eu,www.easyconferences.eu

Cover layout by (c) Raphaël Savina (raphael@savina.net)

Photo "bridge" on cover by (C) Andriy Markov/Shutterstock

Photo "frog" on cover by (C) Fany Savina (fany.savina@gmail.com)

Fonts used are licensed under a SIL Open Font License

ISBN13: 978-1-908416-43-8 (Paperback - Print on demand, black and white)

Print on demand technology is a high-quality, innovative and ecological printing method; with which the book is never 'out of stock' or 'out of print'.

ISBN13: 978-1-908416-44-5 (Ebook, PDF, colour)

ISBN13: 978-1-908416-45-2 (Ebook, EPUB, colour)

Legal deposit, Ireland: The National Library of Ireland, The Library of Trinity College, The Library of the University of Limerick, The Library of Dublin City University, The Library of NUI Cork, The Library of NUI Maynooth, The Library of University College Dublin, The Library of NUI Galway.

Legal deposit, United Kingdom: The British Library.

British Library Cataloguing-in-Publication Data.

A cataloguing record for this book is available from the British Library.

Legal deposit, France: Bibliothèque Nationale de France - Dépôt légal: décembre 2016. 